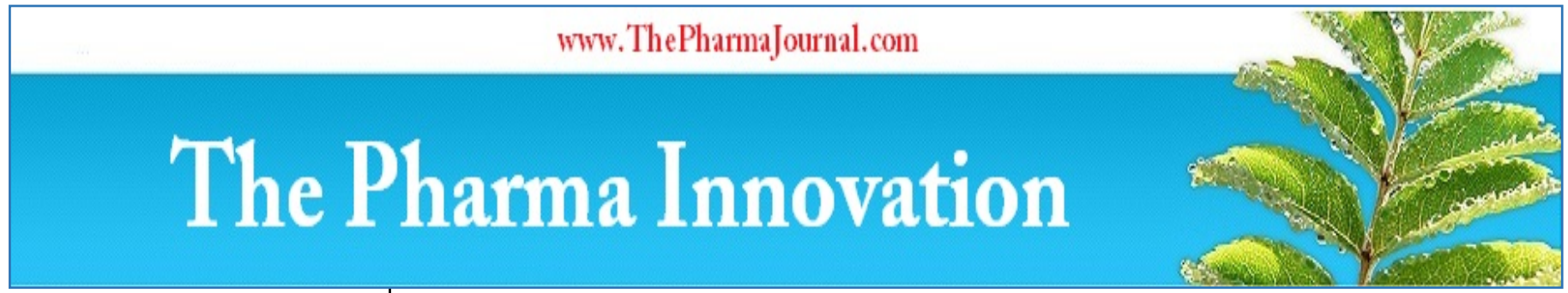

ISSN (E): 2277- 7695

ISSN (P): 2349-8242

NAAS Rating: 5.23

TPI 2021; 10(11): 1817-1821

(C) 2021 TPI

www.thepharmajournal.com

Received: 14-08-2021

Accepted: 19-09-2021

Rajveer Singh Katoriya

Ph.D., Scholar, Department of

Horticulture and Vegetable

Science, RVSKVV, Gwalior,

Madhya Pradesh, India

Karan Vir Singh

Senior Scientist, Department of

Horticulture, RVSKVV,

Gwalior, Madhya Pradesh, India

Rudhra Pratap Singh Gurjar Ph.D., Scholar, Department of Horticulture, ITM University Gwalior, Madhya Pradesh, India

Corresponding Author: Rajveer Singh Katoriya Ph.D., Scholar, Department of Horticulture and Vegetable Science, RVSKVV, Gwalior, Madhya Pradesh, India

\section{Effect of seed priming on drumstick (Moringa oleifera L.) seedling growth with different concentrations of gibberellic acid}

\author{
Rajveer Singh Katoriya, Karan Vir Singh and Rudhra Pratap Singh Gurjar
}

DOI: https://doi.org/10.22271/tpi.2021.v10.i11z.9153

\begin{abstract}
The moringa is a higher consumer preferable and nutritious vegetable tree whose propagation with seeds \& cutting. Seed, sexual propagation is effective and commercially profitable. A pot experiment on Effect of seed priming on drumstick (Moringa oleifera L.) seedling growth with different concentrations of gibberellic acid, was carried out during kharif season at Department of Horticulture, College of Agriculture, Rajmata Vijayaraje Scindia Krishi Vishwa Vidyalaya, Gwalior (M.P.). The experiment was laid out in Complete Randomized Design with eight treatments and three replications. Observations of the characters under study of drumstick plants were recorded from five randomly selected plants from each treatment. The data was recorded as per the standard procedure and analyzed statistically as per design. For each observation, five seedlings per treatment were selected randomly. The observations were recorded on growth parameters viz. height of seedling $(\mathrm{cm})$, number of leaves per seedling, diameter of stem $(\mathrm{mm})$ and length of shoot $(\mathrm{cm})$ at 25 and 45 days after seed sowing. While, root length $(\mathrm{cm})$, root diameter (mm), fresh and dry weight of root (g), fresh and dry weight of shoot (g), fresh and dry weight of seedling (g), and survival percentage of seedling observed at 45 days after seed sowing. Maximum height of seedling $(22.82 \mathrm{~cm}$ and $38.62 \mathrm{~cm})$, number of leaves per seedling (83.51 and 107.25), diameter of stem $(5.37 \mathrm{~mm}$ and $7.83 \mathrm{~mm})$, length of shoot $(19.15 \mathrm{~cm}$ and $30.31 \mathrm{~cm})$ at 25 and 45 days after seed sowing, maximum root length $(8.31 \mathrm{~cm})$, root diameter $(3.56 \mathrm{~mm})$, fresh and dry weight $(13.29 \mathrm{~g}$ and $4.03 \mathrm{~g}$ ) of shoot, fresh and dry weight $(6.01 \mathrm{~g}$ and $1.94 \mathrm{~g})$ of root, fresh and dry weight $(19.30 \mathrm{~g}$ and $5.97 \mathrm{~g})$ of seedling and survival percentage (81.33\%) at 15 days after transplanting of seedling was recorded with seed soaked in 10ppm GA3 for 24 hours.
\end{abstract}

Keywords: Drumstick, moringa, murrugi, sahjan, gibberellic acid, soaking time

\section{Introduction}

Drumstick (Moringa oleifera L.) also known as 'Horseradish tree', 'Mullakkai', 'Murrugi', 'Sahjan' and 'Muringa'. Moringa is an important vegetable tree belongs to the single genius family Moringaceae and grown mainly in the semi-arid, the tropical and subtropical regions. Moringa grown best where temperatures range from $25^{\circ} \mathrm{C}-38^{\circ} \mathrm{C}$ and annual rainfall at least $500 \mathrm{~mm}$. It is multi-purpose, fast-growing tree, all parts of which can be used in various ways, including for food (Hsu et al., 2006) ${ }^{[6]}$ and medicinal purposes (Fuglie, 2001) ${ }^{[4]}$. Drumstick fresh leaves contain 19.3 - 26.4 per cent crude protein which are essential for livestock (Aregheore, 2002) ${ }^{[2]}$. Its Leaves are also rich in vitamin-C seven times more than orange, calcium and protein four times and two times more than milk, Potassium three times more than banana, iron three times more than Indian spinach and vitamin A four times more than carrot (Anonymous. 2010; Hossain et al. 2012) ${ }^{[1,5]}$. The seeds of moringa contain a colourless, oil known as "Ben", "Benhen”, or "Benhenen oil" which have high market-value of olive oil, and is considered to be a substitute for sperm whale oil, often used for lubricating purposes (Booth and Wickens, 1998) ${ }^{[3]}$. Moringa is propagated sexually through seeds, and vegetatively through stem cuttings seed propagation is best than vegetative. Propagation through seeds which are usually planted in the nursery using a light media (3/1 proportion), mixture of soil and sand, respectively. Priming is a technique in which seeds are soaked in different solutions with high osmotic potential. This prevents the seeds from absorbing enough water for radicle protrusion, thus suspending the seeds in the lag phase (Taylor et al., 1998) ${ }^{[9]}$. Hydropriming involves soaking seeds in water before sowing. The seed needs to be wet to soften the seed coat and a pre-soak provides this necessary moisture. Hydration method of priming is sufficient to allow pre-germination, early growth and increased metabolic activation to take 
place, but insufficient to allow radical protrusion through the seed coat. Hormonal priming technique may enhance seed germination, growth and seedling uniformity. Currently, synthetic growth regulators have received wide spread acceptance and application in the field of horticulture. Now a days various uses of growth regulators, seed germination, initiation of rooting, enhancing growth of the cutting is most useful to the growers. The treated cutting rapidly produces a uniform and extensive root system, which when transplanted survives better than untreated cuttings. Among the different plant growth regulators, auxin is most effective as a rooting aid. Auxins stimulate adventitious root formation in stem cutting. Gibberellic Acid $\left(\mathrm{GA}_{3}\right)$ is the most important growth regulator, which breaks seed dormancy, promotes germination, hypocotyls growth and cell division in cambial zone and increases the size of leaves. $\mathrm{GA}_{3}$ stimulates hydrolytic enzymes that are needed for the degradation of the cells surrounding the radicle and thus initiate germination by promoting seedling elongation growth of cereal seeds (Rood et al. 1990) ${ }^{[8]}$. Optimum socking time and concentration of growth regulator (Gibberellic acid) is important to help in enhancing seedling growth of drumstick.

\section{Materials and Methods}

\section{Experiment location and site}

The Investigation was carried out at experimental field of department of Horticulture, College of Agriculture, RVSKVV Gwalior (M.P.). The experimental field of Department of Horticulture, College of Agriculture, Gwalior is located at $26^{\circ}$ $13^{\prime} \mathrm{N}$ latitude and $78^{\circ} 14^{\prime} \mathrm{E}$ longitude at a height of $211.5 \mathrm{~m} \mathrm{~m}$ elevated from the mean sea-level in the Agro-climatic region of Madhya Pradesh. The rainfall is occurred during mid-June till September \& occasionally occur during winters. The climate of experimental area is sub-tropical with hot and dry summers where maximum temperature exceeds up to $45^{\circ}-47^{\circ}$ $\mathrm{C}$ in May-June. During winter the minimum temperature as low as $2{ }^{\circ} \mathrm{C}$ in December and January. The frosting may occur from mid-January to first week of February.

\section{Details of the experiment}

The experiment consists eight treatments and three replications under Complete Randomized Design (CRD). The treatments include, Different soaking time of seeds i.e. 24 hours, 48 hours with different concentrations gibberellic acid i.e. $5 \mathrm{ppm}$, 7.5ppm, and 10ppm.

\section{Source of seed}

The freshly healthy and sound PKM-1 seeds were taken from department of horticulture, college of agriculture Gwalior (M.P.).

\section{Nursery Preparation}

Nursery was prepared with mix the of soil, sand and vermicompost in a proportion of 2:1:1 and treated with the solution of Captan @ 0.2\% uniformly then lefted it for 24 hours. Then after total 720 polythene bags (18x12 cm size) were filled with this prepared growing media.

\section{GA3 solutions prepared for Seed's treatment}

Required quantity of gibberellic acid i.e., $5 \mathrm{mg}, 7.5 \mathrm{mg}$ and 10 mg were weighted with the help of an electronic balance. Then after balance different quantities of gibberellic acid were transferred separately into different glass beakers. Then, after transferred different quantity of $\mathrm{GA}_{3}$ dissolved with the help of 95\% ethyl alcohol. In each concentration of gibberellic acid containing labeled beakers, $1000 \mathrm{ml}$ of distilled water was added in to make the solution of 5ppm, 7.5ppm and 10ppm.

\section{Soaking of seeds in different treatment}

90 seeds in each treatment were soaked for 24 hours and 48 hours.

\section{Experiment management \\ Seeds sowing}

After completion of 24 hours and 48 hours of seeds soaking, seeds were removed from beakers and one seed sown in each polythene bags with the two-to-three-centimeter depth

\section{Pinching}

Pinching was done to strengthen uniform growth of moringa plants and also removing over topped leaves to make maximum use of space.

\section{Irrigation}

Light irrigation was given just after sowing of seeds in each treatment and subsequent irrigations was given uniformly, as and when required depending upon climatic conditions.

\section{Weeding}

Two hand weeding were done at 15 and 30 days after seed sowing for minimized weed infestation.

\section{Plant Protection Measures}

Plant Protection measures were uniformly used when infestation occur at different stages of the experiment.

\section{Observations}

For observations, five seedlings per treatment were selected randomly. The observations were recorded on growth parameters viz. Height of seedling $(\mathrm{cm})$, the height of seedling measure from the root tip to primary leaf with the help of measuring scale at 25 \& 45 days after sowing. Number of leaves per seedling, the no. of leaves per seedling in each treatment was counted at 25 and 45 days after sowing and averaged it. Diameter of stem (mm), diameter was measured at center of the stem length at 25 and 45 days after seed sowing with the help of vernier caliper and mean stem diameter was expressed in millimeter. Length of shoot $(\mathrm{cm})$, shoot length measure from the collar region to the tip of the shoot at 25 and 45 days after seed sowing and mean shoot length was expressed in centimeter. Root length $(\mathrm{cm})$, it was measured from lower collar portion to the tip of primary root at 45 days after sowing and means root length was expressed in centimeter. Root diameter (mm), it was measured at center of the root length with the help of vernier caliper at 45 days after sowing and mean root diameter was expressed in millimeter. Fresh weight of shoot (g), measurement of shoot fresh weight was taken by weighing of fresh shoots at 45 days after seed sowing with the help of weighing balance and expressed in grams. The data were recorded as per standard procedure and analyzed statistically as per design. Dry weight of shoot (g), fresh shoots kept in an oven maintained at 80 ${ }^{\circ} \mathrm{C} \pm 1{ }^{\circ} \mathrm{C}$ for twenty-four hours. After drying, the weight of dried shoot was recorded with the help of electronic weighing machine and means weight was calculated and expressed in grams. It was taken at 45 days after seed sowing. Fresh weight of root (g), fresh root was taken for measuring fresh weight of root. It was observed at 45 days after sowing with 
the help of weighing balance and expressed in grams \& analyzed. Dry weight of root (g), fresh root kept in an oven maintained at $80^{\circ} \mathrm{C} \pm 1^{\circ} \mathrm{C}$ for twenty-four hours. After drying, the weight of dried root was recorded with the help of electronic weighing machine and means weight was calculated and expressed in grams. It was taken at 45 days after seed sowing.

Fresh weight of seedling (g), fresh weight of seedling was calculated by summing of already measured fresh weight of shoot and root of same seedling and expressed in gram.

Dry weight of seedling (g), dry weight of seedling was calculated by summing of already measured dry weight of shoot and root of same seedling and expressed in gram.

Survival percentage of seedling. It was calculated at 15 days after transplanting with the help of following formula.

Survivability $(\%)=\frac{\text { Total No. of seedlings survived }}{\text { Total no. of seedlings transplanted }} \times 100$

\section{Statistical analysis}

The experimental data were noted and analyzed using Complete Randomized Design (CRD) technique suggested by Panse and Sukhatme (1985) ${ }^{[7]}$. The critical differences for the treatment comparisons were worked out, wherever the " $F$ " test was found significant at $5 \%$ level of significance.

\section{Results and Discussion \\ Growth studies \\ Height of Seedling (cm)}

The data presented in Table 1 reveals that the maximum height of seedling $(22.82 \mathrm{~cm}$ and $38.62 \mathrm{~cm})$ was recorded with seed soaked in 10ppm $\mathrm{GA}_{3}$ for 24 hours $\left(\mathrm{T}_{4}\right)$ followed by seed soaked in 10ppm $\mathrm{GA}_{3}$ for 48 hours $\left(\mathrm{T}_{8}\right)(21.19 \mathrm{~cm}$ and $36.93 \mathrm{~cm}$ ), seed soaked in 7.5ppm $\mathrm{GA}_{3}$ for 24 hours $\left(\mathrm{T}_{3}\right)$ $(20.56 \mathrm{~cm}$ and $36.82 \mathrm{~cm})$ at 25 and 45 days after seed sowing, respectively. While, Minimum height of seedling was recorded with seed soaked in normal water for 48 hours $\left(\mathrm{T}_{5}\right)$ $(12.99 \mathrm{~cm}$ and $27.09 \mathrm{~cm})$ followed by seed soaked in normal water for 24 hours $\left(\mathrm{T}_{1}\right)(15.12 \mathrm{~cm}$ and $29.31 \mathrm{~cm})$ at 25 and 45 days after seed sowing, respectively. However, seed soaked in normal water for 24 hours was found at par with seed soaked in normal water for 48 hours at 25 days after seed sowing.

\section{Number of leaves per seedling}

The data presented in Table 1 indicated that the maximum number of leaves per seedling (83.51 and 107.25) was recorded with seed soaked in 10ppm $\mathrm{GA}_{3}$ for 24 hours $\left(\mathrm{T}_{4}\right)$ followed by seed soaked in 10ppm $\mathrm{GA}_{3}$ for 48 hours $\left(\mathrm{T}_{8}\right)$ (81.81 and 104.12), seed soaked in 7.5ppm GA $\mathrm{F}_{3}$ for 24 hours $\left(\mathrm{T}_{3}\right)$ (79.11 and 102.63) at 25 and 45 days after seed sowing, respectively. However, there was no significant difference recorded between seed soaked in 10ppm GA $\mathrm{p}_{3}$ for $24\left(\mathrm{~T}_{4}\right)$ and $48\left(\mathrm{~T}_{8}\right)$ hours at 25 days after seed sowing; seed soaked in 10ppm $\mathrm{GA}_{3}$ for 48 hours $\left(\mathrm{T}_{8}\right)$ and seed soaked in 7.5ppm $\mathrm{GA}_{3}$ for 24 hours $\left(\mathrm{T}_{3}\right)$ at 25 and 45 days after seed sowing. Minimum number of leaves per seedling was recorded with seed soaked in normal water for 48 hours $\left(T_{5}\right)$ (60.43 and 82.53) followed by seed soaked in normal water for 24 hours $\left(\mathrm{T}_{1}\right)$ (64.12 and 85.15) at 25 and 45 days after seed sowing, respectively.

\section{Diameter of Stem (mm)}

The data presented in Table 2 reveals that diameter of stem was significantly increased with increasing the concentration of $\mathrm{GA}_{3}$ under both the soaking times at 25 and 45 days after seed sowing over seed soaked in normal water. Maximum stem diameter $(5.37 \mathrm{~mm}$ and $7.83 \mathrm{~mm})$ was recorded with seed soaked in 10ppm $\mathrm{GA}_{3}$ for 24 hours $\left(\mathrm{T}_{4}\right)$ followed by seed soaked in 10ppm $\mathrm{GA}_{3}$ for 48 hours $\left(\mathrm{T}_{8}\right)(5.16 \mathrm{~mm}$ and $7.64 \mathrm{~mm})$, seed soaked in 7.5ppm $\mathrm{GA}_{3}$ for 24 hours $\left(\mathrm{T}_{3}\right)$ $(4.92 \mathrm{~mm}$ and $7.32 \mathrm{~mm})$ at 25 and 45 days after seed sowing, respectively. However, similar concentrations of $\mathrm{GA}_{3}$ was at par with each other under both the soaking times at 25 and 45 days after seed sowing.

Minimum stem diameter was recorded with seed soaked in normal water for 48 hours $\left(\mathrm{T}_{5}\right)(2.55 \mathrm{~mm}$ and $5.06 \mathrm{~mm})$ followed by seed soaked in normal water for 24 hours $\left(T_{1}\right)$ $(2.71 \mathrm{~mm}$ and $5.27 \mathrm{~mm})$ at 25 and 45 days after seed sowing, respectively. However, seed soaked in normal water for 24 hours $\left(T_{1}\right)$ was found at par with seed soaked in normal water for 48 hours $\left(T_{5}\right)$ at 25 and 45 days after seed sowing.

\section{Length of shoots (cm)}

The data for various treatments in respect to length of shoot was summarized in Table 2. Result indicated that the different seed soaking treatments were affected to shoot length of drumstick. The seed soaked in $10 \mathrm{ppm} \mathrm{GA}$ solution for 24 hours $\left(\mathrm{T}_{4}\right)$ was exhibited maximum shoot length $(19.15 \mathrm{~cm}$ and $30.31 \mathrm{~cm}$ ) followed by seed soaked in $10 \mathrm{ppm} \mathrm{GA}_{3}$ for 48 hours $\left(\mathrm{T}_{8}\right)(17.58 \mathrm{~cm}$ and $29.11 \mathrm{~cm})$ and seed soaked in 7.5ppm $\mathrm{GA}_{3}$ solution for 24 hours $\left(\mathrm{T}_{3}\right)(17.47 \mathrm{~cm}$ and $29.26 \mathrm{~cm}$ ) at 25 and 45 days after seed sowing, respectively. However, both the follower treatments were at par with each other at both the crop growth stages. Higher concentration of $\mathrm{GA}_{3}$ under both the soaking times was also at par with each other at 25 days after seed sowing.

Minimum shoot length $(9.91 \mathrm{~cm}$ and $21.76 \mathrm{~cm})$ was noted with seed soaked in normal water for 48 hours $\left(\mathrm{T}_{5}\right)$ followed by seed soaked in normal water for 24 hours $\left(T_{1}\right)(11.90 \mathrm{~cm}$ and $23.46 \mathrm{~cm})$ at 25 and 45 days after seed sowing, respectively.

\section{Root length (cm)}

It is clearly evident from the Table 3 indicated that the root length was significantly influenced by different treatments. Maximum root length $(8.31 \mathrm{~cm})$ was taken by seed soaked in 10ppm $\mathrm{GA}_{3}$ for 24 hours $\left(\mathrm{T}_{4}\right)$ followed by seed soaked in $10 \mathrm{ppm} \mathrm{GA}_{3}$ for 48 hours $\left(\mathrm{T}_{8}\right)(7.82 \mathrm{~cm})$, seed soaked in 7.5ppm $\mathrm{GA}_{3}$ for $24\left(\mathrm{~T}_{3}\right)$ and $48\left(\mathrm{~T}_{7}\right)$ hours $(7.56 \mathrm{~cm}$ and $7.38 \mathrm{~cm})$, respectively. However, there was no significant difference found between both the soaking times at similar $\mathrm{GA}_{3}$ concentrations except higher concentration.

Minimum root length $(5.33 \mathrm{~cm})$ was recorded with seed soaked in normal water for 48 hours $\left(\mathrm{T}_{8}\right)$ followed by seed soaked in normal water for 24 hours $\left(\mathrm{T}_{1}\right)(5.85 \mathrm{~cm})$.

\section{Root diameter (mm)}

The data for various treatments in respect to root diameter was summarized in Table 3 . Result indicated that seed soaked in 10ppm $\mathrm{GA}_{3}$ solution for 24 hours $\left(\mathrm{T}_{4}\right)$ exhibited maximum root diameter $(3.56 \mathrm{~mm})$ followed by seed soaked in $10 \mathrm{ppm}$ $\mathrm{GA}_{3}$ for 48 hours $\left(\mathrm{T}_{8}\right)(3.41 \mathrm{~mm})$, seed soaked in 7.5ppm $\mathrm{GA}_{3}$ solution for 24 hours $\left(\mathrm{T}_{3}\right)(3.38 \mathrm{~mm})$ and 48 hours $\left(\mathrm{T}_{7}\right)$ $(3.26 \mathrm{~mm})$ these were at par with each other. Whereas, minimum root diameter $(2.71 \mathrm{~mm})$ was noted with seed soaked in normal water for 48 hours $\left(T_{5}\right)$ followed by seed soaked in normal water for 24 hours $\left(T_{1}\right)(2.82 \mathrm{~mm})$, which was at par with each other. 


\section{Fresh weight of shoot (g)}

The data pertaining in the Table 3 is clearly evident that the fresh weight of shoot was significantly increased with increasing $\mathrm{GA}_{3}$ concentration under both the soaking times. Significantly maximum fresh weight of shoot (13.29g) was taken by seed soaked in 10ppm $\mathrm{GA}_{3}$ for 24 hours $\left(\mathrm{T}_{4}\right)$ followed by seed soaked in 10ppm $\mathrm{GA}_{3}$ for 48 hours $\left(\mathrm{T}_{8}\right)$ (12.61g) and seed soaked in 7.5ppm $\mathrm{GA}_{3}$ for 24 hours $\left(\mathrm{T}_{3}\right)$ (11.72g).

Minimum fresh weight of shoot (7.73g) was recorded with seed soaked in normal water for 48 hours $\left(T_{5}\right)$ followed by seed soaked in normal water for 24 hours $\left(\mathrm{T}_{1}\right)(8.37 \mathrm{~g})$ which was at par with each other.

\section{Dry weight of shoot (g)}

The data summarized in Table 3. Result indicated that the different seed soaking treatments significantly affected the dry weight of shoot. The seed soaked in 10ppm GA 3 solution for 24 hours $\left(\mathrm{T}_{4}\right)$ was observed with maximum dry weight of shoot (4.03g) followed by seed soaked in 10ppm $\mathrm{GA}_{3}$ for 48 hours $\left(\mathrm{T}_{8}\right)(3.82 \mathrm{~g})$, seed soaked in 7.5ppm GA 3 solution for 24 hours $\left(\mathrm{T}_{3}\right)$ (3.35g) and 48 hours $\left(\mathrm{T}_{7}\right)$ (3.21g). Whereas, minimum dry weight of shoot (2.21g) was noted with seed soaked in normal water for 48 hours $\left(T_{5}\right)$ followed by seed soaked in normal water for 24 hours $\left(\mathrm{T}_{1}\right)(2.52 \mathrm{~g})$ which was at par with each other.

\section{Fresh weight of root (g)}

The data summarized in Table 4. Result indicated that the different seed soaking treatments were significantly affected to root diameter.

The seed soaked in 10ppm GA 3 solution for 24 hours $\left(\mathrm{T}_{4}\right)$ was exhibited maximum fresh weight of root (6.01g) followed by seed soaked in 10ppm $\mathrm{GA}_{3}$ for 48 hours $\left(\mathrm{T}_{8}\right)$ (5.72g) which was at par with each other. While, minimum fresh weight of root (3.87g) was noted with seed soaked in normal water for 48 hours $\left(T_{5}\right)$ followed by seed soaked in normal water for 24 hours $\left(\mathrm{T}_{1}\right)(4.01 \mathrm{~g})$ which was at par with each other.

\section{Dry weight of root (g)}

The data pertaining in the Table 4 is clearly evident that dry weight of root was significantly increased with increasing $\mathrm{GA}_{3}$ concentration under both the soaking times. Maximum dry weight of root (1.94g) was taken by seed soaked in 10ppm $\mathrm{GA}_{3}$ for 24 hours $\left(\mathrm{T}_{4}\right)$ followed by seed soaked in 10ppm $\mathrm{GA}_{3}$ for 48 hours $\left(\mathrm{T}_{8}\right)(1.83 \mathrm{~g})$ and seed soaked in 7.5ppm $\mathrm{GA}_{3}$ for 24 hours $\left(T_{3}\right)(1.78 g)$. However, these were statistically at par with their follower treatment. The minimum dry weight of root $(0.77 \mathrm{~g})$ was recorded with seed soaked in normal water for 48 hours $\left(T_{5}\right)$ followed by seed soaked in normal water for 24 hours $\left(T_{1}\right)(0.88 \mathrm{~g})$ which was at par with each other.

\section{Fresh weight of seedling (g)}

The data pertaining in the Table 4 is clearly evident that the fresh weight of seedling was increased with increasing $\mathrm{GA}_{3}$ concentration under both the soaking times. Maximum fresh weight of seedling (19.30g) was taken by seed soaked in 10ppm $\mathrm{GA}_{3}$ for 24 hours $\left(\mathrm{T}_{4}\right)$ followed by seed soaked in 10ppm $\mathrm{GA}_{3}$ for 48 hours $\left(\mathrm{T}_{8}\right)(18.33 \mathrm{~g})$ and seed soaked in 7.5ppm $\mathrm{GA}_{3}$ for 24 hours $\left(\mathrm{T}_{3}\right)$ (17.34g) which was at par with each other. Minimum fresh weight of seedling (11.60g) was recorded with seed soaked in normal water for 48 hours $\left(T_{5}\right)$ followed by seed soaked in normal water for 24 hours $\left(T_{1}\right)$ (12.38g) which was at par with each other.

\section{Dry weight of seedling (g)}

The data summarized in Table 4. Results indicated that the different seed soaking treatments were significantly affected to dry weight of seedling. An increase in $\mathrm{GA}_{3}$ concentration significantly increased the dry weight of seedling. The seed soaked in 10ppm $\mathrm{GA}_{3}$ solution for 24 hours $\left(\mathrm{T}_{4}\right)$ exhibited maximum dry weight of seedling $(5.97 \mathrm{~g})$ followed by seed soaked in 10ppm $\mathrm{GA}_{3}$ for 48 hours $\left(\mathrm{T}_{8}\right)$ (5.65), seed soaked in 7.5ppm GA $\mathrm{A}_{3}$ solution for 24 hours $\left(\mathrm{T}_{3}\right)(5.13 \mathrm{~g})$ and 48 hours $\left(\mathrm{T}_{7}\right)$ (4.73g). Whereas, minimum dry weight of seedling (2.97g) was noted with seed soaked in normal water for 48 hours $\left(T_{5}\right)$ followed by seed soaked in normal water for 24 hours $\left(T_{1}\right)(3.40 \mathrm{~g})$ which was at par with each other.

\section{Survival percentage of seedling}

The data on survival percentage of seedling presented in Table 4 revealed that it was significantly increased with increasing $\mathrm{GA}_{3}$ concentration under both the soaking times.

The maximum survival percentage $(81.33 \%)$ was recorded with seed soaked in 10ppm $\mathrm{GA}_{3}$ for 24 hours $\left(\mathrm{T}_{4}\right)$ followed by seed soaked in 10ppm $\mathrm{GA}_{3}$ for 48 hours $\left(\mathrm{T}_{8}\right)(78.32 \%)$ and seed soaked in 7.5ppm $\mathrm{GA}_{3}$ for 24 hours $\left(\mathrm{T}_{3}\right)(78.17 \%)$, which was at par with each other. Seed soaked in $5 \mathrm{ppm}$ and 7.5ppm $\mathrm{GA}_{3}$ for 24 hours ( $\mathrm{T}_{2}$ and $\mathrm{T}_{3}$ ) was found at par with seed soaked in 7.5ppm and 10ppm $\mathrm{GA}_{3}$ for 48 hours ( $\mathrm{T}_{7}$ and $\mathrm{T}_{8}$ ), respectively. While, minimum survival percentage of seedling (55.64\%) was noted with seed soaked in normal water for 48 hours $\left(T_{5}\right)$ followed by seed soaked in normal water for 24 hours $\left(\mathrm{T}_{1}\right)(61.67 \%)$.

Table 1: Effect of seed priming and concentrations of Gibberellic acid on height and number of leaves per seedling

\begin{tabular}{|c|c|c|c|c|}
\hline \multirow{2}{*}{ Treatments } & \multicolumn{2}{|c|}{ Height of seedling (cm) } & \multicolumn{2}{c|}{ Number of leaves per seedling } \\
\cline { 2 - 4 } & 25 DAS & 45 DAS & 25 DAS & 45 DAS \\
\hline Seeds soaking in water for 24 hours & 15.12 & 29.31 & 64.12 & 85.15 \\
\hline GA3 5ppm for 24 hours & 19.88 & 34.57 & 76.21 & 98.26 \\
\hline GA3 7.5ppm for 24 hours & 20.56 & 36.82 & 79.11 & 102.63 \\
\hline GA3 10ppm for 24 hours & 22.82 & 38.62 & 83.51 & 107.25 \\
\hline Seeds soaking in water for 48 hours & 12.99 & 27.09 & 60.43 & 82.53 \\
\hline GA3 5ppm for 48 hours & 18.12 & 33.73 & 74.37 & 95.96 \\
\hline GA3 7.5ppm for 48 hours & 19.85 & 35.02 & 78.3 & 99.37 \\
\hline GA3 10ppm for 48 hours & 21.19 & 36.93 & 81.81 & 104.12 \\
\hline S.E.(m) \pm & 0.72 & 0.45 & 1.14 & 0.77 \\
\hline C.D. (at 5\%) & 2.16 & 1.37 & 3.45 & 2.33 \\
\hline
\end{tabular}


Table 2: Effect of seed priming and concentrations of Gibberellic acid on diameter of stem and length of shoots

\begin{tabular}{|c|c|c|c|c|}
\hline \multirow{2}{*}{ Treatments } & \multicolumn{2}{|c|}{ Diameter of stem (mm) } & \multicolumn{2}{c|}{ Length of shoots (cm) } \\
\cline { 2 - 4 } & 25 DAS & 45 DAS & 25 DAS & 45 DAS \\
\hline Seeds soaking in water for 24 hours & 2.71 & 5.27 & 11.90 & 23.46 \\
\hline GA3 5ppm for 24 hours & 4.1 & 6.88 & 16.45 & 27.46 \\
\hline GA3 7.5ppm for 24 hours & 4.92 & 7.32 & 17.47 & 29.26 \\
\hline GA3 10ppm for 24 hours & 5.37 & 7.83 & 19.15 & 30.31 \\
\hline Seeds soaking in water for 48 hours & 2.55 & 5.06 & 9.91 & 21.76 \\
\hline GA3 5ppm for 48 hours & 3.79 & 6.68 & 14.74 & 26.91 \\
\hline GA3 7.5ppm for 48 hours & 4.81 & 7.08 & 16.35 & 27.64 \\
\hline GA3 10ppm for 48 hours & 5.16 & 7.64 & 17.58 & 29.11 \\
\hline S.E.(m) \pm & 0.12 & 0.1 & 0.56 & 0.39 \\
\hline C.D. (at 5\%) & 0.35 & 0.3 & 1.68 & 1.19 \\
\hline
\end{tabular}

Table 3: Effect of seed priming and concentrations of Gibberellic acid on root length, root diameter, fresh weight of shoot and dry weight of shoot

\begin{tabular}{|c|c|c|c|c|}
\hline Treatments & Root length (cm) & Root diameter (mm) & Fresh weight of shoot (g) & Dry weight of shoot (g) \\
\hline & 45 DAS & 45 DAS & 45 DAS & 45 DAS \\
\hline Seeds soaking in water for 24 hours & 5.85 & 2.82 & 8.37 & 2.52 \\
\hline GA3 5ppm for 24 hours & 7.11 & 3.23 & 10.69 & 3.08 \\
\hline GA3 7.5ppm for 24 hours & 7.56 & 3.38 & 11.72 & 3.35 \\
\hline GA3 10ppm for 24 hours & 8.31 & 3.56 & 13.29 & 4.03 \\
\hline Seeds soaking in water for 48 hours & 5.33 & 2.71 & 7.73 & 2.21 \\
\hline GA3 5ppm for 48 hours & 6.82 & 3.14 & 10.39 & 2.92 \\
\hline GA3 7.5ppm for 48 hours & 7.38 & 3.26 & 11.37 & 3.21 \\
\hline GA3 10ppm for 48 hours & 7.82 & 3.41 & 12.61 & 3.82 \\
\hline S.E.(m) \pm & 0.15 & 0.07 & 0.22 & 0.11 \\
\hline C.D. (at 5\%) & 0.31 & 0.2 & 0.67 & 0.32 \\
\hline
\end{tabular}

Table 4: Effect of seed priming and concentrations of Gibberellic acid on fresh weight of root, dry weight of root, fresh weight of seedling, dry weight of seedling and survival percentage of seedlings

\begin{tabular}{|c|c|c|c|c|c|}
\hline Treatments & $\begin{array}{c}\text { Fresh weight of root } \\
\mathbf{( g )}\end{array}$ & $\begin{array}{c}\text { Dry weight } \\
\text { of root (g) }\end{array}$ & $\begin{array}{c}\text { Fresh weight of } \\
\text { seedling (g) }\end{array}$ & $\begin{array}{c}\text { Dry weight of } \\
\text { seedling (g) }\end{array}$ & $\begin{array}{c}\text { Survival percentage } \\
\text { of seedlings }\end{array}$ \\
\hline & 45 DAS & 45 DAS & 45 DAS & 45 DAS & 15 DAT \\
\hline Seeds soaking in water for 24 hours & 4.01 & 0.88 & 12.38 & 3.4 & 61.67 \\
\hline GA3 5ppm for 24 hours & 5.33 & 1.47 & 16.02 & 4.55 & 75.11 \\
\hline GA3 7.5ppm for 24 hours & 5.62 & 1.78 & 17.34 & 5.13 & 78.17 \\
\hline GA3 10ppm for 24 hours & 6.01 & 1.94 & 19.3 & 5.97 & 81.33 \\
\hline Seeds soaking in water for 48 hours & 3.87 & 0.77 & 11.6 & 2.97 & 55.64 \\
\hline GA3 5ppm for 48 hours & 5.08 & 1.36 & 15.47 & 4.28 & 70.33 \\
\hline GA3 7.5ppm for 48 hours & 5.43 & 1.52 & 16.68 & 4.73 & 74.88 \\
\hline GA3 10ppm for 48 hours & 5.72 & 1.83 & 18.33 & 5.65 & 78.32 \\
\hline S.E.(m) \pm & 0.12 & 0.04 & 0.5 & 0.15 & 2.99 \\
\hline C.D. (at 5\%) & 0.38 & 0.12 & 1.52 & 0.45 & \\
\hline
\end{tabular}

\section{Conclusion}

From the this investigation, we can conclude that among all the treatments, pre sowing seed treatment of drumstick seeds with soaking in 10ppm $\mathrm{GA}_{3}$ concentration for 24 hours was found to be the most suitable for all the parameters of seedling growth and survival of drumstick seedlings.

\section{Acknowledgments and funding}

The authors are grateful to the authorities of the university, Hon'ble Vice chancellor, Dr S.K. Rao, Director Instructions, Dr A.K. Singh, Dean Faculty of Agriculture, Dr Mridulla Billore, Dean, College of Agriculture, Gwalior, Dr J.P. Dixit, Professor and Head, Deptt of Horticulture, Dr R. Lekhi for providing all support during the research work.

\section{References}

1. Anonymous 2010. http://e-articles.info/e/a/title/Moringaoleifera-::-The-Miracle-Tree.

2. Aregheore EM. Intake and digestibility of Moringa oleifera batiki grass mixtures for growing goats. Small Rum Research 2002;46:23-28.

3. Booth FEM, Wickens GE. Non-timber Uses of Selected Arid Zone Trees and Shrubs in Africa. FAO Conservation
Guide, Rome, Italy 1998, 92-101.

4. Fuglie LJ, Sreeja KV. Cultivation of Moringa. The Miracle Tree, Moringa oleifera: Natural Nutrition for the Tropics. Training Manual. CWS Senegal and CWS Riverside Drive, New York, USA 2001, 123-128.

5. Hossain MM, Miah G, Ahamed T, Sarmin NS. Study on allelopathic effect of Moringa oleifera on the growth and productivity of mungbean. International Journal of Agriculture and Crop Sciences (IJACS) 2012;4(15):11221128.

6. Hsu R, Midcap S, Arbainsyah M, De Witte L. Moringa oleifera: Medicinal and Socio-Economic Uses. International Course on Economic Botany, National Herbarium Leiden, The Netherlands 2006, 18.

7. Parera Panse VG, Sukhatme PV. Statistical methods for Agricultural Workers, ICAR, New Delhi 1985;15(2):164168.

8. Rood SB, Buzzell RI, Major DJ, Pharis RP. Gibberellins and heterosis in maize: quantitative relationship. Crop Science 1990;30:281-6.

9. Taylor AG, Allen PS, Bennett MA, Bradford KJ, Burrisand JS, Misra MK. Seed enhancements. Seed Science Research 1998;8:245-256. 